\title{
[1]
}

1 JOURNAL OF ECONOMIC ISSUES

Vol. XVIII No.3 September 1984

\section{The Endogenous Flow of Credit and the Post Keynesian Theory of Money}

Marc Lavoie

The aim of this article is to show that there exists an alternative view on monetary matters, a view distinct from both the neo-quantitative view of the monetarists and from the so-called neoclassical synthesis, as represented by authors such as Edmond Malinvaul, James Tobin, or Paul Samuelson. I shall attempt to show that this alternative view is shared by economists from both sides of the Atlantic, and that their different contributions form a coherent whole. This alternate monetary theory I shall call "post Keynesian." It is part of this new post Keynesian paradigm, as presented by Alfred Eichner and Jan Kregel, said to describe genuine monetary production systems: "On the view presented here, that postKeynesian theory deals with a monetized production economy in Keynes's sense, there can be no analysis of money separate from the overall actions of the system" [Eichner and Kregel 1975, p. 1309, fn. 39].

As I understand it, the term "post Keynesian" describes those economists who attempt to carry on J. M. Keynes's creative attempt to break with tradition. Typical authors in the field of monetary economics and finance are: in Britain, Nicholas Kaldor and Richard Kahn; in the United

The author is Assistant Professor of Economics, University of Ottawa. All quotes by French economists have been translated by the author. I would like to thank Jacques Henry, Mario Seccareccia (both from the University of Ottawa), Alain Parguez (from the University of Besançon in France), and all three anonymous referees of the journal. Of course, they cannot be held responsible for any extreme statement that could be left in this final version. I also want to thank my teammate Eli Sukunda for his help. 
States, Paul Davidson, Hyman Minsky, and Basil Moore. Several French economists may also be added to the list. As pointed out by Davidson and Sidney Weintrauh [1981], this list would not correspond to the names that Samuelson would attach to his "Post Keynesian" brand. This is why an extensive definition is required.

One can say that "orthodox" monctarists face critics from three different sides. First, there are the partisans of rational expectations, who go to the extreme limits of Milton Friedman's framework, and who sometimes draw opposite conclusions. ${ }^{1}$ Secondly, there is the usual neoclassical synthesis critique, represented by the "Bastard" or "Hydraulic" Keynesians, most of whom have anachronistically joined the ranks of the monetarists." These Keynesians accept the ideas presented by monetarists in the late sixties and carly seventies-for instance, the natural rate hypothesis or Friedman's aphorism that inflation is always and everywhere a monetary phenomenon. At the same time, they attempt to keep intact pieces of their grand neoclassical synthesis puzzle. The overall result, as pointed out by members of the two other sides [Lucas 1981; Minsky 1981], is totally incoherent critique and a theory in shambles.

The third side of the critique is the post Keynesian. Whereas the first two critiques were "internal" critiques (based, along with the monetarist model, upon some version of a general equilibrium model), the post Keynesian critique is "external" to monetarism, because it rejects any formulation of neoclassical general equilibrium. The foundations of post Keynesian theory are radically different from those advocated by the "Invisible College." Post Keynesian theory is nonetheless perceived as either a theory without money or else as a theory without any distinctive features [Tarshis 1980, p. 4; Yellen 1980, p. 19]. Surely, this must be attributed to the fact that post Keynesian theory has mainly been known through its growth models (the Cambridge models of growth and distribution), which except for comments made by Joan Robinson [1956, chaps. 3, 23, 24], Davidson [1972, chaps. 5, 12,13], and Kaldor [1966], deal very little with monetary matters. The same, a fortiori, can be said of the neoRicardian school. Furthermore, until the early seventies, post Keynesian monetary theory was still influenced by the textbook interpretation of Keynes." The similarities with the "Bastard" Keynesians' position can be partly attributed to the strength of tradition, to Keynes's own position, and to the desire to use a common language. ${ }^{+}$With the advent of monetarism, however, post Keynesians have been forced to present explicitly their monetary framework, that is, to integrate explicitly financial considerations within their view of the functioning of a capitalist economy. 


\section{Credit Money as a Flow}

Keynes came very close to describing the monetary production economy in which we live [Kregel 1980, p. 33]. The most explicit statements are not to be found in the General Theory or in the Treatise on Money; they are to be discovered in the various sketches of the General Theory, which appeared as early as 1932. In these drafts, Keynes describes what he calls an "entrepreneur economy," that is, a true modern economy where the fluctuations of effective demand are a monetary phenomenon. The main characteristic of this entrepreneur economy is that the reward of the factors of production is not set $a$ priori in real terms; on the contrary, as payments to households are made with money, neither the workers, the rentiers, nor the entrepreneurs know their final share of the national output [Rotheim 1981].

According to orthodox economics, money can appear only as the result of the injection of some high-powered money by the government or because some economic units (usually consumers) intend to modify their portfolios. These approaches are variations on the well-worn monetarist theme. They cannot in any way explain the existence of a monetarized economy in Keynes's sense. Neoclassical and Bastard Keynesian economists emphasize this portfolio approach because it sets money in the usual neoclassical static framework. Money is predominantly seen as an asset, as a stock, which can be augmented or reduced according to the whims of the central bank or according to those of households. Money is held by households, despite its low or non-existent yield, because of its usefulness for exchanging goods already produced. Since neoclassical economics is founded on scarcity, money-as all other economic resourcesmust be scarce to be of some value. Hence the amount of money at any time must be a given stock, as for any other scarce commodity.

The integration of money in the economic system must not be done when output is already specified, as in the exchange economy of general equilibrium models or even in models à la Clower-Leijonhufvud [Davidson and Weintraub 1973, pp. 1121-32; Davidson 1977; Barrère 1979; Parguez 1977], but rather money must be introduced as part of the production process. Such a process is inherently dynamic, as entrepreneurs in each period must produce a new flow of commodities. Those who organize production require access to existing resources, mainly human labor. This access is provided by credit-moncy. Any flow of production requires a flow of new credit or the renewal of past flows of credit. The banking system creates the necessary credit. Households have no role to 
play in the creation of credit. Borrowers are the causal factor, as emphasized by A. B. Cramp [1971]. Their motivation to accept the burden of a debt is their desire to produce and their hope to realize a surplus. Industry and production, being dynamic concepts, cannot be explained by substitution effects designed for static behavior (that is, portfolio theory).

When entrepreneurs determine the effective demand, they must plan the level of production, prices, distributed dividends, and the average wage rate. Any production in a modern or in an "entrepreneur" economy is of a monetary nature and must involve some monetary outlays. When production is at a stationary level, it can be assumed that firms have at their disposal sufficient cash to finance their outlays. This working capital, in the aggregate, constitutes credits that have never been repaid. ${ }^{5}$ When firms want to increase their outlays, however, they clearly have to obtain extended credit lines or else additional loans from the banks: "Such increased spending can only be paid out of new debt" [Ranson 1983, p. 906]. These flows of eredit then reappear as deposits on the liability side of the balance sheet of banks when firms use these loans to remunerate their factors of production. Money does not fall like manna from heaven; on the contrary it appears when corporations (or the government if corporations are reluctant) are prepared to distribute revenues to households.

A monetary economy goes much further than supposing that part of investment is financed through banking loans; any production in a modern or in an "entrepreneur" economy is of a monetary nature and must involve some monetary outlays." Money is introduced into the economy through the productive activities of the firms, as these activities generate income. There can be no money without production. As pointed out by Will E. Mason [1980-81, p. 240], no sophisticated analysis is required to justify the introduction of money at the level of production: "It follows from the simple fact that incomes are paid in money." It has also been underlined by Bernard Ducros:

It is the payment of wages with money which explains that money becomes the instrument of settlement for all transactions- the fact that purchases of goods are made with money does not justify the payment of wages in monetary units. To admit this is to admit that money intervenes when revenues are being distributed rather than when they are spent [1978, p. 23],

This emphasis on production and credit explains why post Keynesians are more concerned about the asset side of commercial banks than they are about the liability side, which corresponds in part to the stock of money. Any expansion process must be started through new loans [Moore 
1979, p. 127; Eichner 1979 , p. 40]. Therefore, to understand the functioning of a monetary economy, one must recognize that the basic function of the banking system is to create new monetary units that make production (and, to a lesser extent, consumption) possible. The function of financial intermediation is relegated to the backstage, since this function is the offspring of the orthodox linkage that runs from collecting deposits (and excess reserves) to making loans. This link cannot make any sense in a post Keynesian analysis [Levy-Garboua and Weymuller 1979, p. 142]. Albert Wojnilower [1980], for instance, describes the recent U.S. monetary history from the point of view of credits and their availability instead of analyzing the behavior of money aggregates.

In what follows, we make use of the term "money stock." It should be clear, however, that the decisive factor according to the post Keynesian view is the flow of credits. In talking of the "stock of money," we are yielding to convention and habit of mind. The money stock is in fact the resulting factor of the expansion of credit. It can explain neither employment nor prices. The money stock is a residue and as such it cannot be causal. This implies that economists have generally been looking at the wrong aggregates:

[The] increase in the supply of money is a consequence of increased loan expenditure, not the cause of it. ... In so far as the expenditure is 'financed' by making use of an existing overdraft facility or as a result of a new loan arrangement, there will be an automatic increase in the money supply for the simple reason that the additional expenditure will swell the bank deposits of the recipients [Kaldor and Trevithick 1981, pp. 5-6].

I can testify that to all except perhaps the most indigent of the economic actors, the money stock-in contrast to oil or credit-is a meaningless abstraction.... If [M1 balances] were to be promulgated a permanent zero money-growth target, hardly anyone would regard himself as constrained [Wojnilower 1980, p. 324].

Before dealing with this stock of money, a further point should be made. The post Keynesian claim that investment determines savings, rather than the converse [Kregel 1973, pp. 159-60; Moore 1979, p. 128], logically follows, within the context of a monetized production economy, from the causal role played by credit-money. This fact is particularly clear in a growing economy, where the power of access to additional resources is granted to the entrepreneurs by the banking system. In a modern economy, no saving can appear without income being distributed, and no income can be distributed without entrepreneurs getting into debt. Banks make loans to entrepreneurs "without someone having previously trans- 
ferred purchasing power to them" [Cramp 1971, p. 66]. Therefore, investment plans can be made and carried on without there being any need to consider savings plans. ${ }^{7}$ Several important implications can then be drawn, one of which is that savings cannot be the dynamic element of a development strategy [Junker 1967; Ranson 1983].

\section{A Major Theme for Post Keynesians: \\ The "Endogeneity" of the Money Stock}

In contradistinction to orthodox Keynesians, who ignored most aspects of a monetary economy, and in contradistinction to monetarists and all their converts who preach the exogenous aspects of the stock of money, post Keynesians claim that the major part of the money stock arises for endogenous reasons. One can find strong post Keynesian statements in this regard:

Post-Keynesians, in sharp contrast to monetarists, regard the stock of money as being essentially endogenous, responding and accommodating to changes in the level of money wages [Moore 1979, p. 125].

What then, governs ... the changes in 'money supply'?' In my view, it is largely a reflection of the rate of change in money income and, therefore, is dependent on, and varies with, all the forces, or factors, which determine this magnitude [Kaldor 1970, p. 16].

Other post Keynesians prefer to recognize that the stock of money has endogenous as well as exogenous aspects. For instance:

There can thus be a good deal of both 'endogeneity' and 'exogeneity' in [the Monetary Authority] M actions [Weintraub 1978, p. 75].

The money supply can be expanded exogenously (i.e., by the deliberations of the central bank) or endogenously when the banking system responds to an increased demand for money [Davidson 1980, p. 303].

Weintraub and Davidson believe this because they attach some importance to portfolio reshuffling. However, this does not mean that the central bank can directly affect the demand for loans and credit.

It can be said that post Keynesians demonstrate the incoherence of the monetarists' theses in four stages. In a first step, post Keynesians show that the existence of a credit multiplier, as a result of some exogenous control by the monetary authorities, does not necessarily imply a causality running from high-powered money (monetary base or central bank money) to the money stock. On the contrary, causality runs from higher 
credit needs, to higher bank deposits, to higher required reserves. Secondly, post Keynesians argue that central banks generally prefer to accommodate the needs of commercial banks. Thirdly, even if central banks attempt to control the stock of money, they can do so only through the level of interest rates. Finally, post Keynesian theory claims that it can be done only at the cost of disrupting financial markets. A monetary policy based on the supply of money is thus useless or destabilizing.

\section{The Credit Multiplier}

Milton Friedman and Anna Schwartz have defined a monetary multiplier (which many claim to be simpiy tautological) with the help of the identities they derive from their definitions of the money stock and of central bank money [Friedman and Schwartz 1963a, pp. 790-91]. ${ }^{8}$ Since the monetary base $(B)$ is defined as the sum of the reserves of the commercial banks $(R)$ plus the currency in the hands of the public $(C)$, whereas the money stock $(M)$ is equal to this same currency plus the deposits of the public at the counters of the commercial banks $(D)$, one can obtain the following well-known equality:

$$
M=B /[R / D)+(C / M)-(R C / D M)]
$$

According to the monetarists, the central bank should have no problem in controlling the level of the monetary base $(B)$. Furthermore, the reserves/deposits ratio $(R / D)$ is fixed by the legal reserves coefficient (at least, with respect to its minimum value), which is imposed by the central bank, whereas the degree of preference of the public for cash $(C / M)$ is thought to be sufficiently stable. The central bank can thus impose the money stock of its choice, through open-market operations. These operations allow the central bank to control $R$, the reserves of the commercial banks, and hence it can control $B$, the amount of high-powered money. Monetarists generally admit that the ratios $C / M$ and even $R / D$ are not constant, but they claim that the demand for money has been proven to be a sufficiently stable variable. Hence, the main source of the fluctuations of the money stock must be seen from the supply-side: the central banks and the variations of the monetary base $(B)$ are usually held as the culprits.

Although most economists today accept some form of the deposit multiplier principle (it suffices one to browse through textbooks to become convinced of this), only monetarists believe that, even in the short run, it is enough to control $B$ to be able to control $M$. The Bank of Canada, which declared itself of monetarist allegiance as early as 1975 , does 
not try to control directly the stock of money by reading off the level of reserves of chartered banks [Courchene 1979, p. 605].$^{9}$ The same applies to most "morietarist" central banks, including the Federal Reserve. The short-term fluctuations in the values of the credit multiplier, as observed in the past, are too wide to assure that the rates of growth of $M$ and $B$ will be parallel and to guarantee that controlling one parameter will enable one to predict the behavior of the other parameter [Clinton and Lynch 1979 , p. 3]. However, these controversies are only quarrels within the monetarist framework. Much more important is the question about the causality between the monetary base and the stock of money.

The shape of equation ( 1 ) being given, monetarists could just as well argue that the main sources of the variations of high-powered money $(B)$ happen to be the fluctuations of the money stock $(M)$. Monetarists prefer the reverse relationship because they believe that the monetary authorities are successful in attempting to impose their policies upon the banking institutions. This means that bankers, because they stand in dread of bankruptcy or because they fear losing their privileges, are aware of and prefer to comply with the actions initiated by the monetary authorities. The latter are "dynamic," they take initiatives, they do not hesitate to put constraints on the banking system or to pursue policies that could be detrimental (at least in the short run) to the survival of some banks or to the stability of the financial system. If monetary authorities are indeed dynamic, and if they do not fear going against the opinions voiced by the commercial banks, then, argues Victoria Chick [1977, p. 89], there is no doubt that the supply of money is exogenous. For post Keynesian economists, however, money is in some sense endogenous whether central banks are dynamic or not. We shall see later in what sense.

\section{The Credit "Divisor"}

To sum up the monetarist point of view, which, for causality purposes, is similar to the view endorsed by the great majority of economists, one can use equation (2):

$$
M=m B
$$

where $m$ is the monetary multiplier, and where causality is read from right to left, $B$ being the independent variable while $M$ is the dependent one.

On the other hand, the post Keynesian view can be summarized by equation (3):

$$
B=(1 / m) M
$$


where $1 / m$ is the so-called credit divisor; $B$ is the dependent variable and $M$ is the independent variable. As a matter of fact, this equation cannot be found explicitly in any of the post Keynesian writings, but it is clear that such a relationship is implied by a large segment of the post Keynesian literature. ${ }^{10}$

The choice between the multiplier and the divisor is a function of the opinions one has about general equilibrium. If one believes that money appears as the result of production processes, that is, as a consequence of the flow of credit created for entrepreneurs by commercial banks, then the multiplier is unacceptable since money becomes a sort of residue, which is incompatible with general equilibrium theorizing. Furthermore, central banks are generally engaged in "defensive" operations, that is, they act according to equation ( 3 ).

Post-Keynesians rank the supportive responsibilities of central banks above their control duties [Moore 1979, p. 126].

The function of central banks therefore is not to stabilize the economy so much as to act as a lender of last resort. This they are able to do [Minsky 1982, p. 176].

As long as the central bank attempts to stabilize interest rates, as pointed out by Victoria Chick $[1977$, p. 89, fn. 1], the supply of money adapts itself to the demand for money, instead of the reverse. What is perhaps less obvious is that the central bank can operate only upon the level of interest rates, as is explained in the next section. But how can the large monetarist empirical evidence be justified within the post Keynesian context?

According to Nicholas Kaldor [1970, p. 8], the historical stability of the credit multiplier is mainly a result of the fact that monetary authorities generally have an accommodating behavior. They have consistently refused to apply severe pressures on the liquidity of the banking system. ${ }^{11}$ If such pressures were exercised, the various economic units would use all sorts of subterfuges to avoid the utilization of money (currency or checking accounts). There would be a move from banking activities toward non-banking financial activities, as explained by John Gurley and Edward Shaw: Banks would encourage the transformation of demand deposits for term deposits; large firms would start acting as banking institutions and credits between companies would be extended [Gurley and Shaw 1960]. As a consequence the velocity of money as defined by the authorities would be on the rise. For these reasons, monetary authorities realize that they must show some flexibility, otherwise private financial 
institutions and their customers would try to extricate themselves from this very constraining hold and create new kinds of money. As long as restrictions are bearable, the supremacy of the central bank stays unchallenged. The relationship between the central bank and the commercial banks is very similar to that between the vassals and their suzerain. Kaldor has used an equivalent picture: "The Federal Reserve or the Bank of Englarid are in the position of a constitutional monarch: with very wide reserve powers on paper, the maintenance and continuance of which are greatly dependent on the degree of restraint and moderation shown in their exercise" [Kaldor 1970, p. 9].

It is clear that the theory of "moral suasion," according to which the central bank can regulate the banking system without having recourse to laws or (immediate) sanctions, should not be considered a one-way street. The central bank must face an insidious "moral suasion": it must comply with decisions taken and the environment created by the commercial banks. Otherwise, the central bank may lose whatever control it has on financial operations, cither because ( financial or non-financial) economic units would attempt to diminish their needs for banking money and highpowered money, or because financial markets would have been thrown into a pessimistic frenzy, following the bankruptcy of a few banks. Since the government cannot let things get out of hand, and since all economic units are aware of this, the central bank is in a rather awkward position: "[Trade unionists] know that if they stick to their claims no government will permit the liquidity erises, bankruptcies, and widespread loss of employment that strict adherence to a money target implies.... The acceptance of full-employment policy is an institutional change that presents a dilemma" [Kregel 1979, p, 235, fn, 58].

The above quote could just as well apply to bankers. They know that governments have to mect their responsibilities (although some governments nowadays do not seem to consider themselves responsible for the full employment of the labor force) and that central banks must act as lenders of last resort. Provided that the individual commercial banker feels that he is respecting his own "rules of thumb," he cares very little about the liquidity of the whole system, unless there is some "moral" agreement with the central bank. Such an agreement is almost a requirement when the banking sector behaves oligopolistically because in such a case, the likelihond of the hankruptcy of a bank is very small. Therefore, the threat of such an event is not efficient. On the other hand, since no liquidity crisis is likely to arise as a result of restrictive monetary policies, the central hank is bound to tighten the screw for a longer period within an oligopolistic banking system. This is because the eentral bank does not 
fear to disrupt financial markets, although non-financial institutions are badly affected by the financial crunch.

\section{Endogenous Money Supply or Money Demand?}

By adopting the concept of the credit divisor, post Keynesians reject the causality implicit in the formulation of the credit multiplier. Consequently, they also reject the direction of the causality between the money stock and the value of aggregate output, as suggested by the old quantitative school and as somehow proposed anew by the monetarists. This is usually written as:

$$
M V=P Q
$$

where $M$ is the independent variable. Joan Robinson has been rather sarcastic about the monetarist interpretation of this equation: "If the quantity equation had been read in the usual way, with the dependent variable on the left and the independent variable on the right, though rather vague, it would not have been silly" [Robinson 1970, p. 504].

According to post Keynesians, $P Q$ is somehow exogenous, whereas $M V$ is determined by $P Q$. Indeed, $M$ is never considered to be an exogenous variable, except when fluctuations of $V$ cannot allow the previously determined value of $P Q$ to adjust to a fixed $M$, set as an upper bound for $P Q$. This means that the supply of money is generally determined by effective demand as imagined by entrepreneurs, that is, provided the banking system accepts or is in a situation where it can accept providing the required monetary units. Paul Davidson calls this the income-generating finance process [Davidson 1972, p. 227]. When entrepreneurs decide to produce more goods, they must increase their wage-fund as well as their other outlays. They are thus required to ask for more monetary units from the banking system. If the latter is as optimistic as the group of entrepreneurs, it increases its loans to the firms, which brings about an increase of deposits at the banks. Variations in the suppiy of money are therefore caused by fluctuations in prices and quantities of production instead of the reverse.

The leading role, according to Keynes and the post Keynesians, is played by the entrepreneurs and their "animal spirits." Entrepreneurs must foresee what effective demand will be and infer from this the cash outlays they will be required to make in order to pay their factors of production or finance their investments. Once this is done, they can go to the banks and formulate their demand for money. Consequently, as Kaldor explains: "It is never true to say that the level of expenditures on goods 
and services rises in consequence of an increase in the amount of bank money held by the public. On the contrary, it is a rise in the level of expenditure which calls forth an increase in the amount of bank money" [Kaldor 1980, p. 294].

Thure is some identification problem here. As a matter of fact, some monetarists, in particular Friedman and Schwartz [1963, pp. 46-7], assume that the supply of money is independent of the level of income [Mayhew 1983]. This allows them to claim that causation must run from money to income. It also explains how they view the Great Depression: the recession kept on going because the Federal Reserve let the stock of money fall. But this can be true only if the money stock is determined solely by an independent supply of money [Temin 1976, pp. 13-31; Kaldor 1970, pp. 12-15].

We can draw two simple figures to illustrate the position of the monetarists and the "Bastard" Keynesians on the one hand, and the position of the post Keynesians on the other hand. The first givup supposes that the money supply, as set by the actions of the banking system, that is, the central bank, determines the stock of money available in the economy. The central bank must aim at controlling the stock of money rather than the cost of credit (that is, interest rates). This is the Currency School. If the public's demand for money increases, interest rates go up. The additional demand of the public is not met by the banking system, but following a drop in the prices of bonds or other assets, there is a return to equilibrium as a consequence of portfolio adjustments. Within the framework, the money-supply curve is a vertical line.

Post Keynesians, on the other hand, suppose that the money-supply curve is a horizontal line. Commercial banks, or more generally the central bank, set the cost of credit and, at the chosen rate of interest, they stand ready to provide whatever monetary units entrepreneurs see fit to ask for. The responsibility of the monetary authorities, in this new framework, is to control the qualicy of the credits being granted and to make sure that they are "productive." This is the Banking School." Post Keynesians can thus be distinguished from "sythesis" Keynesians for it can be deduced from the preceding analysis that the monetary authorities can control (short-term) interest rates but not the quantity of money.

Now in the case of credit money, the proper representation should be a horizontol 'supply curve' of money, not a vertical one. Monetary policy is represented not by a given quantity of money stock but by a given rate of interest: and the amount of money in existence will be demand-determined [Kaldor 1982, p. 24] 


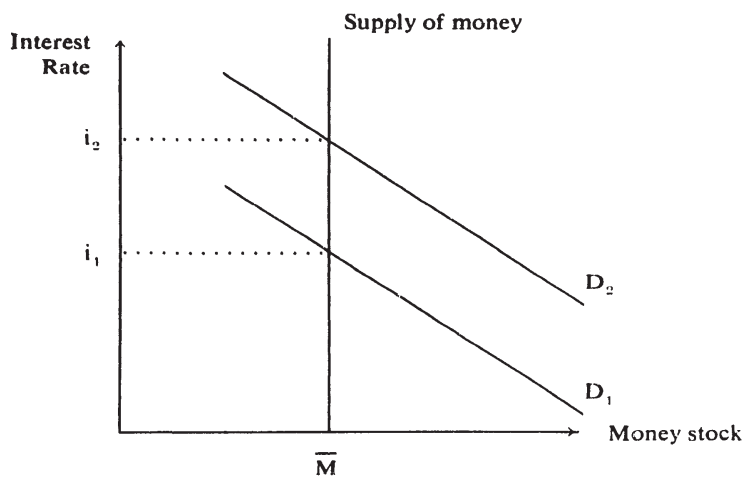

Figure 1.

The economics profession in general must come round to the view that the supply of money is horizontal at every going short-term interest rate.... Central banks can determine the snort-term interest rate at which they will be willing to supply liquidity. But the money stock itself is not a control variable [Moore 1983, p. 555].

This can be seen in Figure 2. An increase in money demand (for purposes of transaction or speculation) corresponds to a shift of the whole demand curve: this leads to an increase in the existing money stock without any change on the part of interest rates. ${ }^{13}$

North American versus European Monetary Institutions

Some economists would argue that the type of framework described in the previous section can be applied only to some monetary systems such as the French or the English systems, where the liquidity of firms and banks depends on the possibility of borrowing from commercial banks and from the central bank respectively. Within these overdraft economies (as they were called by John Hicks and analyzed by Claude Toullec [Hicks 1974, p. 51, Toullec 1979]), the outstanding stock of money is not the result of a market process where various economic units, including the central bank, exchange money for liquid assets, in particular Treasury bills. In overdraft economies, commercial banks may own reserves at the 


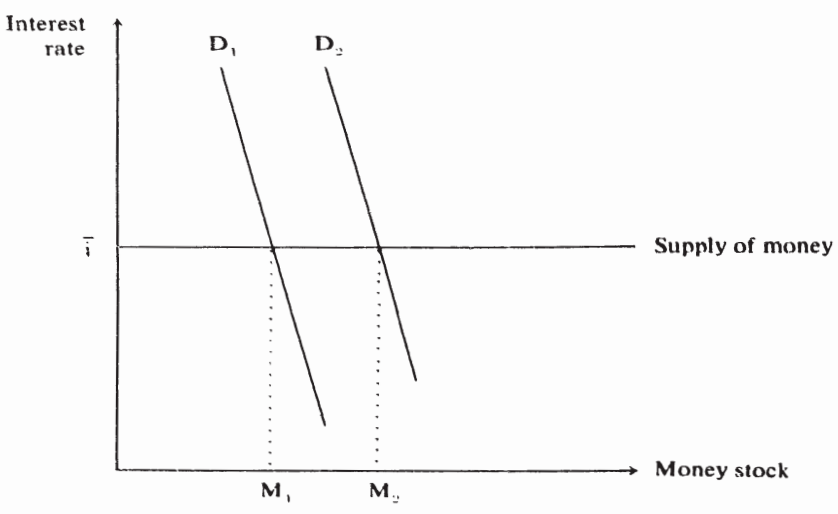

Figure 2.

central bank, but a large part of their liabilities is constituted of advances from the central bank. The latter promises to produce high-powered money, whenever required, at a given rate. Hence French commercial banks first distribute loans and then try to balance their position by borrowing from the central bank.

Although there exists a true money market in the United States and in Canada (the so-called open market), which allows North American banks to have recourse to the advances of the central bank for only very brief periods or else to avoid them altogether, Figure 2 and the corresponding theory of endogenous money apply to these two countries as well. One must remember that the coefficient of legal reserves does not apply to current deposits, but that it applies (by and large) to deposits of the previous month. This implies that, even in historical time, North American banks first consent to additional loans and later attempt to finance their credits on the open market. If the central bank defines a rate above or under which it will intervene, the demand for money will determine the money supply. In any case, commercial banks always have the possibility of recourse to the discount window. This possibility is always exploited in the United States in times of credit crunches. "With lagged reserve accounting, once loans have been granted and deposits created, the monctary authorities have no choice but to provide the banks 
with the necessary required reserves.... Their only decision concerns whether such reserve funds should be provided by open market operations, or whether the banks should be driven to the discount window" [Moore 1981, p. 45].

French economists have always provided an explanation of the increase in the money supply that was not based on high-powered money nor on some other exogenous expansion of free reserves. Despite their different monetary institutions, French economists such as Jean Denizet and JeanGabriel Thomas have always emphasized that the aphorism "credits make deposits" and its consequences applied equally as well to the U.S. banking system [Denizet 1969; Thomas 1981, p. 125]. The principle of the high-powered money multiplier is no more valid in the United States and in Canada than it is in the United Kingdom or in France. Textbook economists usually claim that bankers are naïve in not recognizing that the free reserves of a bank allow the whole monetary system to expand the money supply by a multiple of the amount lent by this bank. In fact, academic economists are the naïve ones, for they do not inquire about the origins of the free reserves. For bankers, including U.S. bankers, larger reserves are provided to the commercial banks as a response to expanding loans. This is made clear by Wojnilower [1980, pp. 324-25], and also by Alan Holmes, who was the System Open Market Account Manager:

[The orthodox idea] suffers from a naive assumption that the banking system only expands loans after the System (or market factors) have put reserves in the banking system. In the real world, banks extend credit, creating deposits in the process, and look for the reserves later.... In any given statement week, the reserves required to be maintained are predetermined by the level of deposits existing two weeks earlier.... Since banks have to meet their reserve requirements each week, and since they can do nothing within that week to affect required reserves, that total amount of reserves has to be available to the banking system [Holmes 1969, pp. 73-74].

Post Keynesians and most French economists believe that central banks have no power over the quantity of money. ${ }^{14}$ They can influence the supply of money only through the impact of interest rates on the demand for money by entrepreneurs, or on the amount of loans that the banks are ready to consent. This is not necessarily related to portfolio effects because it mainly affects those who have liabilities, not those who have assets :

It is therefore totally erroneous to attribute the failure of the FED's monetary policy to a perpetual hesitation between objectives set around the quantity of money, and objectives set around interest rates. The truth 
is that the FED can master interest rates, not quantities. The FED can hope to exercise some action upon the overall money creation of the system through interest rates, and only through them [Thomas 1981, p. 128].

A further point on the subject of Hicksian overdraft economies may be made. It used to be that only British banks offered lines of credit to their customers on a regular basis. But as recently emphasized by Wojnilower [1980, pp. 288-89], the recurrence of credit crunches in the United States has led to the creation of extensive legally binding credit lines. Unused bank-credit commitments are now in excess of demand deposits. Considering the relationship between firms and commercial banks (instead of the one between commercial banks and the central bank, as we have done until now), we see that the U.S. economy is definitely an overdraft economy.

Keynes has shown that unused overdrafts are equivalent to an invisible money supply because a firm may draw a cheque either against its deposits (in which case they are decreased) or against its unused overdraft (in which case its debit with its bank is increased) [Keynes 1930, vol. 1, pp. 41-43]. In both cases, the private bank has to fulfill its obligations and supply the required cash. The value of legally binding credit lines cannot be controlled by open-market operations. Hence, even if there were no lagged reserve accounting, it would be quite impossible for the central bank to control the stock of money or not to provide the necessary reserves.

\section{An Inversion of Causality}

From the above discussion, it would seem that monetarists are the victims of their own methodology. Empiricism has led them to confuse temporal ordering for logical causality [Mason 1980-81, p. 239]. As readers of the "letters to the editor" of The Times of London in the seventies know, some monetarists claim to have discovered a temporal relationship between the stock of money and the value of national income, the former always preceding the latter in empirical time. This justifies, according to monetarists, the one-way causality they have adopted in their analysis. ${ }^{15}$

But neither the idea of a potential control by the central bank nor the concept of an empirically found temporal link can determine in any sense what causality is [Kaldor 1970, p. 10]. Post Keynesians usually propose Keynes's finance motive as a counter-example [Keynes 1973, pp. 20123]. ${ }^{16}$ To demonstrate, in a statistical sense, that a rise in the money stock 
always happens before an expansion of production or an increase in prices cannot be of any help, provided one accepts the principle of effective demand and provided one does not assume that money falls from the sky (thrown out of a helicopter). Those who advocate the existence of the finance motive claim that the demand for money (and hence the money stock) increases initially as a consequence of the additional expenditures that firms expect to realize. Also, some investment expenditures are only recorded upon completion, long after additional funds have been required and obtained. This implies that the temporal sequence-money stock/ income-discovered by the monetarists can have no causal significance at all [Davidson and Weintraub 1973, p. 1118]. In fact, studying the data published by Friedman and Schwartz [1963a] or else by another monetarist, Phillip Cagan [1965], one could just as easily argue that "the dominant direction of causal influence runs from business to money" [Dugger 1980, p. 121 ; cf. Moore 1979a, p. 54].

Recent empirical investigation has also shown that all sorts of statistical correlations could compete with the typical monetarist (temporal) relationship between the stock of money and gross national product. For instance, Benjamin Friedman has now worked for some time on the liability side and has discovered that just as strong a link could be established between the debt of non-financial corporations and nominal national income [Friedman 1981].${ }^{17}$ Raymond Lombra and Raymond Torto have shown, long ago, that the reverse--causation argument could be supported by empirical studies [Lombra and Torto 1973]. Edgar Feige and Robert McGee [1977, pp. 546 47], applying the Sims-Granger detection procedures for "causality," have shown that there was evidence of the stock of money influencing the level of reserves, at least since the introduction of the lagged required reserve accounting conventions in the United States in 1968, whereas it appeared that reserves did not "cause" money. Finally, Moore has demonstrated, using the same type of procedure, that money-wage rates could be said to "cause" increases in the money stock [Moore 1979, pp. 61-64].

All of this empirical work suggests that there are valid alternative interpretations to the views professed by the monetarists or by the standard Keynesian textbooks. From these empirical results and from the previous theoretical scheme, it can be concluded that to increase the value of production firms require supplementary finance. This increase is related to the unit cost of production, that is, the nominal wage rate. ${ }^{18}$ The increase in loans leads to increases in money balances and allows increases in production expenditures. 


\section{Portfolio Effects and Elasticity of Substitution}

Up to now, we have either assumed that the central bank was ready to accommodate the needs of commercial banks or else that central banks were somehow forced to create the reserves required by law from those commercial banks. As a consequence, the stock of money appeared to be mainly the result of an income-generating finance process, where money was mainly the result of decisions pertaining to liabilities and debts. Money, however, is an asset for households and firms, and as such it is part of portfolio theory. It would therefore appear that money cannot be totally endogenous. This has been admitted by Davidson [1972, pp. 22627], Minsky [1982, pp. 280-84], Cramp [1971], and others. What is then the role of portfolio theory and substitution effects within a post Keynesian theory of money and credit?

From the traditional standpoint (monetarists and Keynesians), monetary authorities intervene on the open market by offering such prices for Treasury bills held by financial institutions and households that they cannot afford ignoring such offers and are condemned to modify the structure of their portfolios. Purchases (sales) of these bonds by the central bank induce, in a static framework, a decrease (an increase) in the interest rate of Treasury bills, and an increase (a decrease) in the free money deposits of households and the reserves of commercial banks. The change in the rate of return on bills spreads to all other assets; free reserves are transformed into new loans; the excess part of extra money balances is distributed toward other markets, financial or non-financial (in particular new durable consumer goods).

Post Keynesians recognize all of this [Dow and Earl 1982]. Their interpretation is, however, slightly different. When the central bank decides to increase the money supply, it is simultaneously forcing the public and the banks to shift the composition of their assets. If households decide to spend some of their new cash holdings, it is simply a response to the fall in interest rates. This is nothing other than the well-known classical effect. As to the excess reserves of the banks, they can be depleted only if interest rates on loans are sufficiently low to induce entrepreneurs to increase production, or if the reduced reward on savings accounts encourages households to leave their deposits in the more convenient current accounts. When the central bank decides to decrease free reserves, it can do so only through higher interest rates, which discourages households and firms from keeping demand deposits, and forces some entrepreneurs to abandon production plans. 
Post Keynesians usually assume that the demand for money is interest inelastic, as the monetarists do. ${ }^{10}$ One of the main reasons is that rising (or decreasing) interest rates have very little effect on the behavior of banks and entrepreneurs as long as expectations of future short-term interest rates do not change or unless the monetary authorities announce drastic changes in policy [Kaldor 1964, p. 132; Wojnilower 1980, pp. 278-323; Thomas 1981, p. 138]. It follows that large movements in the level of interest rates are required for the central bank to be able to modify the money supply. A restrictive monetarist policy thus requires wide variations in bond prices to induce a fall in the stock of demand for money. Since such a policy is not possible without disrupting financial markets, the power of the central bank to control the stock of money is severely limited [Kaldor 1970 , p. 8, fn. 2]. In any case, controlling the stock of money as such is useless since money is a residue. The choice for the central bank should be between setting the level of interest rates or controlling bank lending and the extent of credit lines.

Even if households or entrepreneurs somehow wind up with a stock of money that is larger than desired, it is obvious that they are not compelled to get rid of the excess money by buying consumer goods or by ordering investment goods. An economic unit, or even the whole of all economic units, can always diminish the level of its cash holdings by paying back the loans that had been previously granted [Kaldor 1980, p. 294]. The cancellation of the loans leads to the suppression of deposits and consequently to the reduction of the stock of money. Then, commercial banks have excess reserves at their disposal. But these reserves cannot be activated if the public in general, and entrepreneurs in particular, have no desire to get into debt (this is a likely situation if entrepreneurs and households have just decided to reimburse part of their debt). An historical example can be found in the large free reserves of U.S. banks during the Great Depression.

\section{Endogenous Money and Financial Instability}

If monetary authorities always ratify or are forced to ratify the decisions taken by entrepreneurs and bankers, as these authorities always pursue "defensive" policies, then one may wonder why post Keynesians keep claiming that a market economy is inherently unstable. The financial instability hypothesis has mainly been presented by Hyman Minsky [1976; 1982]. This thesis rests on the contractual structure of the economy. Any market economy is basically of a speculative nature, since economic 
units take and carry out decisions in a world of uncertainty. Corporations take risks because they are able to reimburse their borrowings only if they realize the profits that they expected when the initial outlays were made; banks also take risks since their debtors could find themselves short of liquid resources [Wood 1975, pp. 24-32].

Stability breeds instability. The more tranquil the economy, the more entrepreneurs and bankers are ready to indulge in risky ventures. When memories of the last liquidity crisis start to fade into the past, bankers grant loans on easier grounds, for, with constant risks, banking profits are a direct function of the volume of credit accepted by bankers. This slack in the rules of financial conduct on the part of the banking institutions finally modifies the behavior of the corporations: the latter are incited to change the extreme and the normal values of their financial ratios [Minsky 1976, pp. 118-19]. The utilization of ratios that incorporate the value of a company as assessed by the stock exchange leads to the appearance of "virtuous" effects. In periods of expansion, most of the purchases on the stock market are financed through banking loans. Banks grant this type of loan only if they have high expectations. And if these credits are granted, then the expectations oi the banks come true, and firms, as a result of this increase in the stock exchange index, are allowed to get even more into debt. ${ }^{20}$

The financial crisis can appear when some firms refuse to ask for more credits. Minsky argues that in a dynamic economy, firms are always requiring banks to create new loans, which implies that the central bank is always pressured to create new reserves. There are therefore forces that are continuously pushing interest rates upward [Cramp 1971, p. 66]. When the central bank stops accommodating the needs of the banks, interest rates do go up. As we have seen, however, a gradual monetary policy will not do. Any required slowdown necessitates a credit crunch. When this condition is fulfilled, expansion is stopped and it forces firms that went too far in their commitments to ask for additional loans in order to pay back those that have just expired. When banks refuse to finance these roll-overs, there is an impending crisis, as the bankruptcy of one firm entails the collapse of several other firms and even of some banks perhaps [Davidson 1977, p. 555, fn. 1; Minsky 1982, p. 199].

Why do banks bring about their own downfall by refusing to renew the loans that their customers had initially obtained? It follows from the fact that banks are in a situation very similar to that of the entrepreneurs. The latter as a group should be as dynamic as possible, but each entrepreneur taken individually cannot afford to be more optimistic than the average entrepreneur. This is the principle of effective demand. 
How can unemployment be explained? The answer must be found in the principle of effective demand.... In the capitalist system, an entrepreneur with 'animal spirits' which are more optimistic than those of the group constituting the rest of the entrepreneurs is necessarily penalized. Whereas it would be in the interest of all entrepreneurs to have the highest possible 'animal spirits,' it is in the interest of each entrepreneur not to be too optimistic, or at least, not more optimistic than the other entrepreneurs [Grellet 1976, pp. 202-203].

The same principle applies to bankers. A bank gets into trouble only if its spirits are too high, that is, if it lends more than its rivals, for in this case, loans that have been made are not compensated by deposits (unless this particular bank launches a successful publicity campaign). A bank in such a situation has to ask other financial institutions or the central bank for the missing monetary resources, at a cost that could exceed its lending rate.

When bankers begin losing some of their high "animal spirits," though they are aware of the fact that their new behavior will harm the economy, they prefer to restrain their creation of credit-money. They know that those banks that are the least affected by the recession are those banks that show the most moderation. For this reason, it is quite possible for the banking system to start reducing its credit lines just when firms need extended loans. It is difficult to see how the creation of excess reserves by the central bank could reverse this trend.

\section{Conclusion}

It should by now be clear why and how post Keynesian thought on money differs from orthodox monetary theory. The money stock is a residue. Except for speculative periods, which are not dealt with in this essay, money has no role to play. One must look at the other side of the banks' balance sheet for proper information. Money arises as a result of credit, from the needs of firms to pay their factors of production. Money should essentially be understood as income-money and credit-money. Alain Parguez has extensively shown how strange it is to assess the importance of money, as do orthodox economists, by simply measuring the idle part of it, that is, the portion of the monetary flow that is stocked or hoarded [Parguez 1975]. Thus one should stop referring to the exogenous money stock and start considering the endogenous flow of money, or rather the endogenous flow of credit. It is credit-money that matters.

Thus the post Keynesian framework of monetary matters differs much from the portfolio approach of neoclassical Keynesian analysis. The two 
critiques of monetarism must not be confused: the latter is superficial whereas the former is fundamental.

\section{Notes}

1. Frank Hahn's recent critique of monetarism is another version of this type of voyage to the marshes of Friedman's world [Hahn 1982]. Hahn shows that monetarists, once their hypotheses are incorporated into a truly general equilibrium framework, cannot make any claims to scientific conerence.

2. These names have been given scholarly wisdom by Joan Robinson and Alan Coddington [1976].

3. This can be seen mainly in [Robinson 1952]. Richard Chase [1975], and Robert Brazelton [1980-81], have shown the importance of this textbook interpretation for U.S. economists.

4. Kaldor has recently recognized that Keynes's view of the supply of money was more compatible with the standard textbook interpretation than with the new post Keynesian view [Kaldor 1980, p. 296]. In the General Theory, Keynes seems to be dealing with an exogenously determined supply of money.

5. The proof of this statement can be found in [Lavoie 1982a]. It does not imply that corporations make no profits.

6. All production must be financed by credit. This was one of the points raised by Keynes in his response to Bertil Ohlin in 1937 and reiterated in 1939: "It is not an increase of investment as such which requires an immediate increase in 'available funds, 'but an increase of output whether for investment or for consumption, or more strictly an increase in the turnover of transactions for any purpose whatever" [Keynes 1973, p. 282].

7. That firms can grow at the rate that they see fit to choose, whatever the propensity to save of households, has been argued persuasively by Kaldor [1966].

8. For instance [Moore 1979a, p. 55].

9. The Bank of Canada used to publish a weekly series of M1 aggregates, with an accompanying chart comparing the target ranges of the rate of growth of the money supply so defined with the realized rates of growth. The chart was phased out November 29, 1982, following a short period of unexpected negative rates of growth and two years of zero-growth. During the same period M2 has grown by 30 percent (Bank of Canada, Weekly Financial Statistics).

10. The expression "credit divisor" (diviseur cle crédit) was introduced by Jacques Le Bourva [1962]. Kaldor, in his essay on "the new monetarism," does everything but define this concept [1970, pp. 8-10].

11. On the other hand, the theses developed by James Tobin or R. L. Teigen are not compatible with a stable credit multiplier [Tobin 1978: Teigen 1978). Tobin and Teigen assume that banks, as any commercial firm, attempt to maximize their profits within the limits imposed by the cen- 
tral bank, by modifying their portfolios and by encouraging the public to modify theirs. This leads to a fluctuating credit multiplier, instead of the stable monetarist multiplier.

12. For a summary of the Banking School/Currency School controversy, see [M. R. Daugherty $1942 ; 1943]$. Cramp links this controversy to the views of the Radcliffe report [Cramp 1962] (see also [Kaldor 1982, pp. pp. 2-32]).

13. Figure 2 is Jacques Le Bourva's idea [Le Bourva 1959, p. 720]. It can also be found in [Kaidor 1982, p. 24].

14. As pointed out in note 4 above, it is difficult to find any indication of the post Keynesian endogenous money thesis in Keynes's major works [Keynes 1930; 1936]. Furthermore, as noted by Coddington [1976, p. 1262], Keynes's endorsement of Hicks's IS-LM presentation, where the money supply is an exogenously given stock, is a source of embarrassment for post Keynesians. Yet, it is possible to find relevant quotes. Moore has recently linked some of Keynes's writings with the theory of endogenous money supply [Moore 1983a].

15. For excellent critical reviews of Friedman's positive economics, see [Mason 1980-81 and Dugger 1983]. It must however be recognized that some economists of monetarist allegiance sometimes concede that this unidirectional link between money and national income has not yet been successfully demonstrated by empirical research, at least for countries such as Canada or Great Britain [Laidler 1978, p. 157].

16. On the finance motive, see [Davidson 1972, pp. 160-85]. Peter Smith has attempted to identify the empirical significance of the finance motive on the demand for money [Smith 1979].

17. I am indebted to Harvey D. Wilmeth, from Milwaukee, for making me aware of B. Friedman's paper. The latter rightly emphasizes that the available empirical evidence does not warrant an exclusive focus on money rather than credit aggregates. The chosen focus, it appears from Friedman's paper, should result from an econometric investigation of causality, of the Granger-Sims type. His research in that field is, however, inconclusive. Although Friedman is sympathetic to analyses such as the one presented by Albert Wojnilower [1980, comments pp. 327-32], his search for correlations or temporal relations is devoid of economic content. There are not processes, only markets. The same can be said of R. W. Kopke's similar work [Kopke 1983].

18. In the post Keynesian view of inflation, "it is the rise in wages which is the cause of prices rising" [Kahn.1972, p. 138]. Rises in prices are not a consequence of excess money supply or excess aggregate demand [Lavoie 1982, pp. 207-11]. Prices are mainly determined by the money-wage rate. A simple formalized version of this approach to inflation can be found in S. Weintraub [1978], where it is called the "wage-cost markup" theory. Most of it can be found in Keynes's General Theory. The level of money wages depends mainly on social, political, and historical factors. Although accelerating investment or changes in the degree of monopoly can induce price increases, inflation is mainly the result of a struggle between labor groups.

19. The wild fluctuations of interest rates have recently shown that any at- 
tempt by the monetary authorities (most obviously the U.S. Federal Reserve) to control the quantity of money is constrained by the interest inelasticity of the demand for money, as predicted by Kaldor.

20. Minsky thus identifies the main weakness of the theory of endogenous money supply. Not all credit is being crested for production purposes. New loans may be misallocated by banks, in favor of speculation or the expansion of conglomerates, as explained by Veblen [1965, chap. 5]. Post Keynesian theory must consider credit for production as the normal case, but it cannot ignore the anomaly of non-productive credit.

\section{References}

Barrère, Alain. 1979. Déséquilibres économiques et contre-révolution keynésienne. Paris: Economica.

Brazelton, W. Robert. 1980-81. "A Survey of Some Textbook Misinterpretations of Keynes." Journal of Post Keynesian Economics 3 (Winter) : 25670.

Cagan, Phillip. 1965. Determinants and Effects of Changes in the Stock of Money, 1875-1960. New York: Columbia University Press.

Chase, Richard X.1975. "Keynes and the U.S. Keynesianism: A Lack of Historical Perspective and the Decline of the New Economics." Journal of Economic Issues 9 (September): 441-70.

Chick, Victoria. 1977. The Theory of Monetary Policy. Oxford: Parkgate Books.

Clinton, Kevin, and Kevin Lynch, 1979. "Monetary Base and Money Stock in Canada." Technical Report No. 16, Bank of Canada.

Coddington, Alan. 1976. "Keynesian Economics: the Search for First Principles." Journal of Economic Literature 14 (December): 1258-73.

Courchene, Thomas J. 1979. "On Defining and Controlling Money." Canadian Journal of Economics 12 (November) : 604-15.

Cramp, A. B. 1962. "Two Views on Money." Lloyds Bank Review (July): $1-15$.

1971. "Monetary Policy: Strong or Weak?" In Conflicts in Policy Objectives, ed. N. Kaldor. Oxford: Basil Blackwell. Reprinted from Lloyds Bank Review (October 1970).

Daugherty, M. R. 1942. "The Currency-Banking Controversy: Part 1." Southern Economic Journal 9 (October): 140-55. . 1943. "The Currency-Banking Controversy: Part 2." Southern Economic Journal 9 (January): 241-51.

Davidson, Paul. 1972. Money and the Real World. London: Macmillan. 1977. "Money and General Equilibrium." Economie appliquée 30 (Fall) : 541-63. 1980. "The Dual-Faceted Kevnesian Revolution." Journal of Post Keynesian Economics 2 (Spring): 291-307.

Davidson, Paul, and Sidney Weintraub. 1973. "Money as Cause and Effect." Economic Journal 84 (December): 1117-32. 1981. "Jacob and Paul Samuelson, Post Keynesians." Journal of

Post Keynesian Economics 3 (Si'mmer) : 602-604. 
Denizet, Jean. 1969. Monnaie et financement. Paris: Dunod.

Dow, Sheila C., and Peter E. Earl. 1982. Money Matters: A Keynesian Approach to Monetary Economics. Oxford: Martin Robertson.

Ducros, Bernard. 1978. "Les relations entre prix, flux et stocks en analyse de déséquilibre." Economie appliquée 31 (Winter): 15-33.

Dugger, William M. 1980. "The Monetary Experience of U.S. Economic History: A Skeptical Review of Evidence." Journal of Economics 6: 121-25. 1983. "Two Twists in Economic Methodology: Positivism and Subjectivism." American Journal of Economics and Sociology 42 (January): 750-91.

Eichner, Alfred S. 1979. "A Post Keynesian Short-Period Model." Journal of Post Keynesian Economics 1 (Summer) : 38-63.

Eichner, Alfred S., and Jan Kregel. 1975. "An Essay on Post Keynesian Theory: A New Paradigm in Economics." Journal of Economic Literature 13 (December) : 1293-1312.

Feige, Edgar L., and Robert McGee. 1977. "Money Supply Control and Lagged Reserve Accounting." Journal of Money, Credit, and Banking 9 (November) : 536-51.

Friedman, Benjamin. 1981. "The Roles of Money and Credit in Macro-economic Analysis." Working paper (October).

Friedman, Milton, and Anna Schwartz. 1963. "Money and Business Cycles." Review of Economics and Statistics 4 (February): 32-64.

1963a. A Monetary History of the United States, 1867-1960. Princeton: Princeton University Press.

Grellet, Gérard. 1976. "Le principe des avances et la théorie keynésienne de l'emploi." In Controverses sur le système keynésien, ed. A. Barrère. Paris: Economica.

Gurley, John G., and Edward S. Shaw. 1960. Money in a Theory of Finance. Washington: Brookings Institution.

Hahn, Frank H. 1982. Money and Inflation. Oxford: Basil Blackwell.

Hicks, John. 1974. The Crisis in Keynesian Economics. Oxford: Basil Blackwell.

Holmes, Alan R. 1969. "Operational Constraints on the Stabilization of Money Supply Growth." In Controlling Monetary Aggregates. Boston: Federal Reserve Bank of Boston.

Junker, Louis J. 1967. "Capital Accumulation, Savings-Centered Theory, and Economic Development." Journal of Economic Issues 1 (June) : 25-43.

Kahn, Richard F. 1972. "Memorandum of Fvidence Submitted to the Radcliffe Committee (1958)." In Selected Essays on Employment and Growth. Cambridge University Press.

Kaldor, Nicholas. 1964. "Monetary Policy, Economic Stability, and Growth." In Essays on Economic Policy. London: Duckworth. 1966. "Marginal Productivity and the Macro-Economic Theories of Distribution." Review of Economic Studies 33 (October):309-19. . 1970. "The New Monetarism." Lloyds Bank Review (July): 1-17. 1980. "Monetarism and U.K. Monetary Policy." Cambridge Journal of Economics 4 (December) : 292-318.

1982. The Scourge of Monetarism. Oxford: Oxford University Press. 
Kaldor, Nicholas, and James Trevithick. 1981. "A Keynesian Perspective on Money." Lloyds Bank Review (January) : 1-19.

Keynes, John Maynard. 1930. A Treatise on Money. London: Macmillan. 1936. The General Theory of Employment, Interest, and Money. London: Macmillan.

1973. The Collected W'ritings of John Maynard Keynes, vol. 14. London: Macmillan.

Kopke, Richard WV. 1983. "Must the Ideal 'Money Stock' Be Controlled." New England Economic Review (March/April): 10-23.

Kregel, Jain. A, 1973, The Reconstruction of Political Economy: An Introdistion io Post-Keynesian Economics. London: Macmillan. 1979. "From Post-Keynes to Pre-Keynes." Social Research 46 (Summer) : 212-39.

1980. "Markets and Institutions as Features of a Capitalistic Production System." Journal of Post Keynesian Economics 3 (Fall): 32-48.

Laidler, David. 1978, "Money and Money Income: An Essay on the Transmission Mechanism." Journal of Monetary Economics 4 (August): 151-91.

Lavoie, Mare. 1982. "Les post-keynésiens et la monnaie endogène." Actualité économique 58 (January-June) : 191-222.

1982. "Structures financières, endettement et profits." Economie appliqué 35 ( No, 3): 269-300.

Le Bourva, Jacques. 1959, "La théorie de l'inflation, le rapport des experts et l'opèration de decembre 1958." Revue économique 10 (September): 713 54.

1962. "Création de la monnaie et multiplicateur du crédit." Revue èconomique 13 (January) : 29-56.

Levy-Garboua, Vivien, and Bruno Weymuller. 1979. Macroéconomie contemporaine, Paris: Economica.

Lombra, Raymond E., and Raymond G. Torto, 1973. "Federal Reserve 'Defensive' Behavior and the Reverse Causation Argument." Southern Economic Jourmal 40 (July) : 47-55.

Lucas, Robert E. 1981. "Tobin and Monetarism: A Review Article." Journal of Economic Literature 19 (June) : 558-67.

Mason, Will E. 1980-81. "Some Negative Thoughts on Friedman's Positive Economics." Journal of Post Keynesian Economics 3 (Winter) : 235-55.

Mayhew, Anne, 1983. "Ideology and the Great Depression: Monetary History Rewritten." Journal of Economic Issues 17 (June) : 353-60.

Minsky, Hyman P. 1976. John Maynard Keynes, London: Macmillan. 1981. "James Tobin's Asset Accumulation and Economic Activity: A Review Article," Eastern Economic Journal 7 (July-October) : 199-209. 1982. Can "It" Happen Again? Essays on Instability and Finance. Armonk, N.Y.: M. E. Sharpe.

Moore, Basin J. 1979. "Monetary Factors." In A Guide so Post Keynesian Economics, ed. A. S. Eichner. White Plains: M. S. Sharpe.

1981a. "The Endogenous Money Stock." Journal of Post Keynesian Economics 2 (Fall) : 49-70.

1983. "Unpacking the Post Keynesian Black Box: Bank Lending and the Money Supply." Journal of Post Keynesian Economics 5 (Summer) : 537-57. 
1983a. "Keynes and the Endogeneity of the Money Stock." Working Paper, Wesleyan University. 45 pp.

Parguez, Alain. 1975. Monnaie et macroéconomie. Paris: Economica.

1977. "Monnaie et demande effective en déséquilibre." In Economie du déséquilibre. Paris: Economica.

Ranson, Baldwin. 1983. "The Unrecognized Revolution in the Theory of Capital Formation." Journal of Economic Issues 17 (December) : 901-13.

Robinson, Joan. 1952. The Rate of Interest and Other Essays. Macmillan: London.

1956. The Accumulation of Capital. London: Macmillan.

1970. "Quantity Theories Old and New, A Comment." Journal of Money, Credit and Banking 2 (November): 504-12.

Rotheim, Roy J. 1981. "Keynes's Monetary Theory of Value." Journal of Post Keynesian Economics 3 (Summer) : 568-85.

Smith, Peter. 1979. "A Reconsideration of Keynes's Finance Motive." Economic Record 55 (September): 236-42.

Tarshis, L. 1980. "Post-Keynesian Economics: A Promise that Bounced." American Economic Review 70 (May) : 10-14.

Teigen, R. L. 1978. "The Demand for and Supply of Money." In Readings in Money, National Income, and Stabilization Policy, ed. R. L. Teigen. Homewood: R. D. Irwin.

Temin, Peter. 1976. Did Monetary Forces Cause the Great Depression? New York: W. W. Norton.

Thomas, Jean-Gabriel. 1981. Politique monétaire et autodestruction du capital. Paris: Economica.

Tobin, James. 1978. "Commercial Banks as Creators of Money." In Readings in Money, National Income, and Stabilization Policy, ed. R. L. Teigen. Homewood: R. D. Irwin. First published in Deane Carson, ed., Banking and Monetary Studies. Homewood: R. D. Irwin, 1963.

Toullec, Claude. 1979. "Economie du marché, économie d'endettement et politique monètaire." Banque (March) : 291-300.

Veblen, Thorstein. 1965. The Theory of Business Enterprise. New York: Augustus M. Kelley [1904].

Weintraub, Sidney. 1978. Capitalism's Inflation and Unemployment Crisis. Reading, Mass.: Addison Wesley.

Wojnilower, Albert M. 1980. "The Central Role of Credit Crunches in Recent Financial History." Brookings Papers on Economic Activity (No. 2): 277-326.

Yellen, Janet L. 1980. "On Keynesian Economics and the Economics of the Post-Keynesians." American Economic Review 70 (May) : 15-19. 